\title{
Craniofacial Growth in Adolescence and its Influence on the Mandibular Incisor Crowding
}

\section{Kraniofacijalni rast u adolescenciji i utjecaj na zbijenost mandibularnih sjekutića}

\author{
${ }^{1}$ Public Health Centre Ogulin, Croatia \\ Dom zdravlja Ogulin, Hrvatska \\ 2 Department of Orthodontics, Faculty of Dental Medicine, University of Rijeka, Croatia \\ Katedra za ortodonciju Fakulteta dentalne medicine Sveučilišta u Rijeci, Hrvatska \\ ${ }^{3}$ Department of Pediatric Dentistry, Faculty of Dental Medicine, University of Rijeka, Croatia \\ Katedra za dječju stomatologiju, Fakultet dentalne medicine Sveučilišta u Rijeci, Hrvatska \\ ${ }^{4}$ Department of Orthodontics Institute of Clinical Dentistry, University of Oslo, Norway \\ Zavod za ortodonciju, Institut za kliničku dentalnu medicinu, Sveučilište u Oslu, Norveška \\ ${ }^{5}$ Department of Orthodontics Maxillofacial Unit Morriston Hospital, Swansea, United Kingdom \\ Zavod za ortodonciju i Maksilofacijalni odsjek bolnice Morriston, Swansea, Ujedinjeno Kraljevstvo \\ ${ }^{6}$ Department of Dental Medicine, Faculty of Dental Medicine and Health, Josip Juraj Strossmayer University of Osijek, Croatia \\ Katedra za dentalnu medicine Fakulteta za dentalnu medicinu i zdravstvo Sveučilišta Josipa Jurja Strossmayera u Osijeku, Hrvatska
}

\section{Abstract}

Background: To analyze craniofacial growth during adolescence from the ages of 12 to 21 years and its relation to late mandibular incisor crowding. Methods: The study included 61 orthodontically untreated subjects ( $49 \%$ males). Lateral cephalograms were used to assess the jaw growth and inclination of the incisors. Little's Irregularity Index and the anterior mandibular dental arch depth of mandibular dentition were measured. Results: A reduction of the skeletal class angle (ANB) was observed in both genders, although it was significant only in males $(\eta 2=0.188 ; p=0.015)$. The growth of the mandible was more prominent compared to that of the maxilla, and it was more prominent in males than in females. The skeletal vertical dimension, however, demonstrated a significant reduction in both genders $(\eta 2=0.527-0.593, p<0.001)$. The mandibular incisors tended to retrocline in both genders, while the maxillary ones tended to procline in males, and slightly retrocline in females. A decrease in the mandibular dental arch depth occurred in both genders $(\eta 2=0.259 ; p<0.05)$. An in crease in the irregularity of incisors for $1.8 \pm 1.7 \mathrm{~mm}$ on average $(95 \% \mathrm{Cl} 1.3-2.2 ; \eta 2=0.520 ; p<0.001)$ was observed in both genders. A logistic regression revealed that less sagittal growth of maxilla (increase of SNA angle $\leq 2^{\circ}$ ) and reduction of convexity in skeletal sagittal interjaw relationship (reduction of $A N B \geq 1^{\circ}$ ) were significant predictors of the occurrence of crowding ( $\Delta$ Little Irregularity Index $\geq 1 \mathrm{~mm}$ ) yielding odds ratios of 4.9 and 4.8 . Conclusions: The differential growth of the maxilla and mandible is related to the occurrence of late crowding, mostly in smaller amounts in maxillary sagittal growth compared to the mandible.
Received: November 11, 2020

Accepted: January 19, 2021

Address for correspondence Martina Zigante

Kresimirova 40, 51000 Rijeka, Croatia Fax: +38551345650 ,

martina.zigante@uniri.hr

\section{Introduction}

Irregularities in the relationship between teeth and jaws in adult age are related to the development of teeth and the entire craniofacial complex which can be influenced by numerous endogenous and exogenous factors (1-3). Growth is a result of remodeling and shifting, where facial bones grow upwards and backwards and shift downwards and forwards, and the lower jaw reaches the upper one through the development of the ramus and the action of the muscles of mastication $(1,4)$. The alteration of periods of intense and less intense growth, remodeling of the bones through apposition and resorption, development of sinuses, alveolar processes and tooth eruption through continuous changes in facial
Uvod

Nepravilnosti u odnosu zuba i čeljusti u odrasloj dobi povezane su s razvojem zuba i cjelokupnog kraniofacijalnog kompleksa na što mogu utjecati mnogobrojni endogeni i egzogeni čimbenici $(1-3)$. Rast je rezultat preoblikovanja i premještanja, pri čemu kosti lica rastu gore i straga, prostorno pomičući se prema dolje i naprijed, a donja čeljust sustiže gornju razvojem ramusa i djelovanjem žvačnih mišića $(1,4)$. Izmjena razdoblja intenzivnog i manje intenzivnog rasta, preoblikovanje kostiju apozicijom i resorpcijom, razvoj sinusa i alveolarnih nastavaka, nicanje zuba i kontinuirana promjena proporcija kostiju lica stvara odnose koji se vide u odrasloj dobi (4). 
skeleton proportions create relationships which are seen in adult age (4).

Growth can be observed and studied through direct and indirect methods. Direct methods define relationships of reference points directly on the jaws and teeth, and indirect methods use the level of growth or mineralization of certain body parts to determine the skeletal and dental age or sexual maturity of the subject (5-8). Crowding is an occlusal characteristic that becomes more frequent during development of the dentition (9). During adolescence, an occurrence of mandibular incisor crowding is observed, which is believed to be a late expression of primary crowding $(9,10)$. Etiological factors which should be considered are different growth dynamics and rotation of upper and lower jaws, occlusion, dental arch dimensions, tooth size, maturation of soft tissues, masticatory force and the eruption of third molars. (10-12). An early occurrence of late mandibular crowding occurs between the ages of 13 and 18 years and is considered to be mostly caused by maturational factors. Late occurrence of late mandibular crowding occurs after the age of 18 and is probably caused by regressive and degenerative factors $(10,11)$.

The aim of the research was to examine the dynamics of craniofacial growth during adolescence and the extent to which late mandibular crowding is related to the growth and development of the jaws and face. The hypotheses were that during adolescence the mandible grows more than the maxilla, with anterior rotation. It is assumed that both phenomena are more expressed in males than in females. The expected result is dentoalveolar compensation in the form of greater retroclination of lower than the proclination of upper incisors and a decrease in the lower dental arch length. The instance of mandibular incisor crowding is probably more expressed in males and more related to the growth of the mandible than the maxilla.

\section{Material and methods}

This research encompassed data from the Nittedal Growth Study in Norway. The data used are from 61 subjects who had not undergone orthodontic therapy, $49 \%$ of whom were male, observed from 12 to 21 years of age. The Nittedal Study started in Norway in 1972, and the subjects were children born between the years 1958 and 1972 in the Norwegian district of Nittedal. None of the subjects had significant malocclusion or any form of facial disharmony. A smaller number of subjects presented with minimal tooth rotation, less than $1 \mathrm{~mm}$. A lateral cephalogram was obtained for each of the subjects at the age of 12 and 21. It was obtained using the Lumex B device (Siemens, Munich, Germany). The distance of the anode (radiation source) to the mid-sagittal plane was $1.8 \mathrm{~m}$, and the head in the cephalostat was oriented with reference to the Frankfurt horizontal while the teeth were in maximum intercuspation.

A cephalometric analysis was performed on lateral cephalograms in the AudaxCeph program (AudaxCeph, Ljubljana, Slovenia). The following angles were used: sagittal position of the maxilla / maxillary prognathism angle (SNA), sagittal position of the mandible / mandibular prognathism angle
Rast se može promatrati i proučavati izravnim i neizravnim metodama. Izravne metode definiraju odnose referentnih točaka izravno na čeljustima i zubima, a neizravne metode koriste se stupnjem rasta ili mineralizacije određenih dijelova tijela za procjenu skeletne i zubne dobi ili spolne zrelosti ispitanika $(5-8)$. Zbijenost je karakteristika okluzije koja postaje sve češća tijekom razvoja denticije (9). U adolescenciji se uočava pojava zbijenosti mandibularnih sjekutića, tzv. tercijarna zbijenost, za koju se pretpostavlja da je kasna ekspresija primarne zbijenosti $(9,10)$. Mogući etiološki čimbenici su različita dinamika rasta i rotacija gornje i donje čeljusti, okluzija, dimenzije zubnih lukova, veličina zuba, sazrijevanje mekih tkiva, žvačne sile i nicanje trećih kutnjaka (10 -12). Ranija pojava tercijarne zbijenosti u mandibuli događa se između 13. i 18. godine i smatra se da je uglavnom prouzročena maturacijskim čimbenicima. Kasnija pojava tercijarne zbijenosti donje čeljusti pojavljuje se nakon 18. godine i vjerojatno je prouzročena regresivnim i degenerativnim čimbenicima $(10,11)$.

Cilj istraživanja bio je ispitati dinamiku kraniofacijalnog rasta tijekom adolescencije i procijeniti u kojoj je mjeri kasna zbijenost u mandibuli povezana $s$ rastom i razvojem čeljusti i lica. Hipoteze su bile da u adolescenciji mandibula raste više od maksile, uz prednju rotaciju. Pretpostavlja se da su oba fenomena izraženija kod muškaraca negoli kod žena. Očekivani rezultat je dentoalveolarna kompenzacija u obliku veće retroinklinacije donjih sjekutića od proklinacije gornjih sjekutića i smanjenje prednje dužine donjega zubnog luka. Pojava zbijenosti donjih sjekutića vjerojatno je izraženija kod muškaraca i povezanija je s rastom mandibule negoli maksile.

\section{Materijal i metode}

Istraživanje je rađeno na temelju podataka norveške Nittedalske studije rasta. Korišteni su podatci 61 ispitanika koji nisu bili u ortodontskoj terapiji, a praćeni su bili od 12 . do 21 . godine, od kojih su 49 \% činili muškarci. Nittedalska studija počela je u Norveškoj 1972. godine, a ispitanici su bila djeca rođena između 1958. i 1972. godine u norveškome okrugu Nittedal. Nitko od ispitanika nije imao značajnu malokluziju ili bilo koji oblik disharmonije lica. Manji broj ispitanika imao je minimalne rotacije zuba, manje od $1 \mathrm{~mm}$. Svi su imali laterolateralne kefalograme snimljene u dobi od $12 \mathrm{i}$ 21 godine uređajem Lumex B (Siemens, München, Njemač$\mathrm{ka}$ ). Udaljenost anode (izvora zračenja) do srednje sagitalne ravnine bila je 1,8 m, a glava je u kefalostatu bila orijentirana prema Frankfurtskoj horizontali, dok su zubi bili u maksimalnoj interkuspidaciji.

Kefalometrijska analiza provedena je na laterolateralnim kefalogramima u programu AudaxCeph (AudaxCeph, Ljubljana, Slovenija). Korišteni su sljedeći kutovi: sagitalni položaj maksile/kut maksilarnoga prognatizma (SNA), sagitalni položaj mandibule/kut mandibularnoga prognatizma (SNB), sagitalni skeletni obrazac/kut skeletne klase (ANB), vertikalni 
(SNB), sagittal skeletal pattern / skeletal class angle (ANB), vertical skeletal pattern - Bjork's polygon and the interbasal angle (ANS-PNS: M-Go), and inclination of upper and lower incisors in relation to the skeletal maxillary and mandibular plane (13).

Plaster casts of mandibular dentition at 12 and 21 years of age were used to measure the anterior arch depth as the perpendicular from the interpremolar width (the contact point of the first and second premolars) to the most protruding lower incisor as well as the Little's Irregularity Index (14). The Index takes into account anatomical contact points of the anterior teeth and measures the deviation of the contact points. The ideal value of Little's Index is zero, and the value of the index grows with an increase in crowding.

\section{Statistical analysis}

A paired-samples t-test was used to compare the changes in facial and jaw growth parameters between the observed age groups, and an independent samples t-test to compare differences between genders. The effect size was quantified with $\eta 2$ according to the formula $\eta^{2}=t^{2} /\left(t^{2}-d f\right)$, and Cohen's criteria were used for its interpretation: $\eta 2=0.02-0.13=$ small effect size, $0.13-0.26=$ medium and $>0.26=$ large. The $\chi 2$ and Fisher's tests were used to compare the share of crowding categories between the types of craniofacial growth. The effect size was quantified with Cramer V and Cohen criteria for interpretation, based on squared values of $\mathrm{V}$. Correlations of the amount of crowding and changes in parameters of facial and jaw growth were checked on a scatterplot. The existence of linear or nonlinear relationships was checked visually. The Pearson's linear correlations was additionally performed as well as a linear regression where the dependent variable was the degree of crowding change between ages 12 and 21, and the predictors were as follows: gender, change in the maxillary and mandibular prognathism angles, sagittal skeletal class, rotational growth pattern and the anterior depth of the mandibular dental arch. A logistic regression analysis was used to determine which dental and craniofacial characteristics are predictors of the occurrence of crowding in the amounts $>1,>2$ and $>3 \mathrm{~mm}$. Dichotomous variables were used as predictors: gender, $\mathrm{ANB}<1^{\circ}$ at the age of 12 , increase of $S N A<2^{\circ}$, increase of $S N B>2^{\circ}$, reduction of the ANB angle $>1^{\circ}$ and $>2^{\circ}$, reduction of the intermaxillary angle by $>3^{\circ}$, reduction of Bjork's polygon by $>3^{\circ}$, retroclination of mandibular incisors $>2^{\circ}$, proclination of upper incisors $>2^{\circ}$ and reduction of anterior depth $>1 \mathrm{~mm}$. All the statistical analyses were performed using the commercial software IBM SPSS 22 (IBM Corp, Armonk, USA).

\section{Results}

Both genders showed a significant increase in the angles of maxillary and mandibular prognathism with a large effect size $(\eta 2=0.526-0.567 ; \mathrm{p}<0.001)$ and a decrease in the skeletal class angle, which was significant only in males with a medium effect size $(\eta 2=0.188 ; p=0.015$; Figure 1$)$. The mandible grew more than maxilla and more in males than females. The average increase in maxillary sagittal angle was $1.3 \pm 1.2^{\circ}$ (95\% CI 1.0-1.6), mandibular $1.8 \pm 1.6^{\circ}$ (95\% CI 1.4-2.2) skeletni obrazac - Bjorkov poligon i međučeljusni kut (ANSPNS: M-Go) te nagib gornjih i donjih sjekutića na skeletnu bazu (13).

Studijski modeli mandibularne denticije u dobi od $12 \mathrm{i}$ 21 godine korišteni su za mjerenje prednje dužine zubnoga luka kao okomice najprominentnijega donjeg sjekutića na interpremolarnu širinu (kontaktna točka prvoga i drugoga pretkutnjaka) te Littleova indeksa nepravilnosti (14). Indeks uzima u obzir anatomske kontaktne točke prednjih mandibularnih zuba te sumira njihovo odstupanje. Idealna vrijednost Littleova indeksa jest nula, a vrijednost indeksa raste $s$ povećanjem zbijenosti.

\section{Statistička analiza}

Za usporedbu promjena parametara rasta lica i čeljusti između promatranih dobnih skupina korišten je t-test za zavisne uzorke, a za usporedbu razlika između spolova t-test za nezavisne uzorke. Veličina efekta kvantificirana je $s \eta 2$ prema formuli $\eta 2$ = t2 / (t2-df), a za njezino tumačenje korišteni su Cohenovi kriteriji: $\eta 2=0,02-0,13=$ mala veličina efekta, $0,13-0,26=$ srednja i $>0,26=$ velika. $Z a$ usporedbu udjela kategorija zbijenosti između različitih tipova kraniofacijalnog rasta korišteni su $\chi 2$ i Fisherov test. Veličina efekta kvantificirana je $s$ pomoću Cramerova V, a Cohenovi kriteriji za interpretaciju temeljili su se na kvadratnim vrijednostima V. Korelacije iznosa zbijenosti i promjena parametara rasta lica i čeljusti provjerene su na dijagramu raspršenja. Vizualno je provjereno postojanje linearnih ili nelinearnih odnosa. Dodatno su provedene analize Pearsonove linearne korelacije i linearna regresija gdje je zavisna varijabla bila stupanj promjene zbijenosti između 12. i 21. godine, a prediktori spol, promjena kutova maksilarnoga i mandibularnoga prognatizma, kuta skeletne klase, rotacijskog rasta i prednje dužine mandibularnoga zubnoga luka. Logističkom regresijskom analizom analizirano je koje su dentalne i kraniofacijalne karakteristike prediktori pojave zbijenosti $>1,>2 \mathrm{i}>3 \mathrm{~mm}$. Kao prediktori korištene su dihotomne varijable: spol, ANB $<1^{\circ} \mathrm{u}$ dobi od 12 godina, porast $S N A<2^{\circ}$, porast $S N B>2^{\circ}$, smanjenje kuta ANB $>1^{\circ} \mathrm{i}>2^{\circ}$, smanjenje međučeljusnoga kuta $\mathrm{za}>3^{\circ}$, smanjenje Bjorkova poligona $\mathrm{za}>3^{\circ}$, retroinklinacija mandibularnih sjekutića $>2^{\circ}$, proklinacija maksilarnih sjekutića $>2^{\circ}$ i smanjenje prednje dužine zubnoga luka $>1$ $\mathrm{mm}$. Sve statističke analize obavljene su u komercijalnom softveru IBM SPSS 22 (IBM Corp, Armonk, SAD).

\section{Rezultati}

Kod oba spola zabilježeno je značajno povećanje kutova maksilarnoga i mandibularnoga prognatizma $s$ velikom veličinom efekta $(\eta 2=0,526-0,567 ; p<0,001)$ i smanjenje kuta skeletne klase, što je bilo značajno samo kod muškaraca s umjerenom veličinom efekta $(\eta 2=0,188 ; p=0,015$; slika 1). Mandibula je rasla više od maksile te više kod muškaraca negoli kod žena. Prosječno povećanje kuta maksilarnoga prognatizma bilo je $1,3 \pm 1,2^{\circ}$ (95 \% CI 1,0 - 1,6), mandi- 

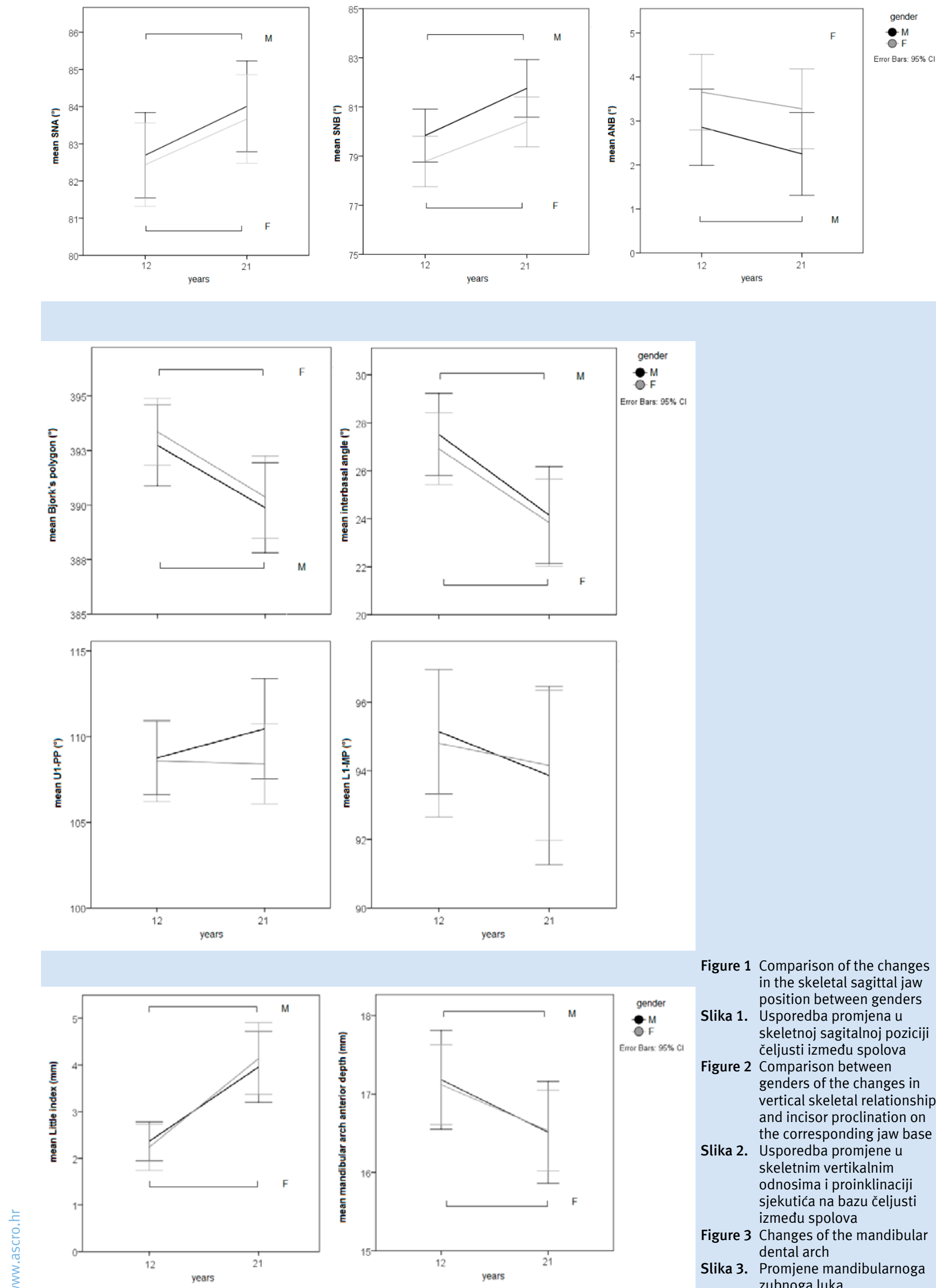

Figure 1 Comparison of the changes in the skeletal sagittal jaw position between genders

Slika 1. Usporedba promjena u skeletnoj sagitalnoj poziciji čeljusti između spolova

Figure 2 Comparison between genders of the changes in vertical skeletal relationships and incisor proclination on the corresponding jaw base

Slika 2. Usporedba promjene $u$ skeletnim vertikalnim odnosima i proinklinaciji sjekutića na bazu čeljusti između spolova

Figure 3 Changes of the mandibular dental arch

Slika 3. Promjene mandibularnoga zubnoga luka 
while skeletal class angle decreased $-0.5 \pm 1.2^{\circ}(95 \%$ CI -0.2 0.8 ). Between the ages of 12 and 21 years, a significant reduction in skeletal vertical dimension occurred in both genders with a large effect size $(\eta 2=0.527-0.593 ; \mathrm{p}<0.001$; Figure 2$)$.

The average decrease in Bjork's polygon was $-2.9 \pm 2.6^{\circ}$ (95\% CI -2.3-(-3.6)), while in the intermaxillary angle it was $-3.2 \pm 2.8^{\circ}$ (95\% CI $\left.-2.5-(-3.9)\right)$. Mandibular incisors showed a tendency for retroclination in both genders (on average $-1.0 \pm 3.9^{\circ}$; $95 \% \mathrm{CI} 0.0-\left(-1.9^{\circ}\right)$ ), while maxillary incisors exhibited proclination in males $\left(1.7 \pm 4.9^{\circ} ; 95 \% \mathrm{CI}-0.1\right.$ $3.5^{\circ}$ ) and a slight tendency toward retroclination in females $\left(-0.2 \pm 3.7^{\circ} ; 95 \%\right.$ CI $\left.-1.6-1.2^{\circ}\right)$; Figure 2$)$. Between the ages of 12 and 21 years, a significant increase of $1.8 \pm 1.7 \mathrm{~mm}$ on average (95\% CI 1.3-2.2; $\eta 2=0.520 ; \mathrm{p}<0.001)$ occurred in Little's Irregularity Index, and those findings were almost identical for men and women (Figure 3). The increase in irregularity of $\geq 4 \mathrm{~mm}$ occurred in $11.5 \%$ of cases, $1-3.9 \mathrm{~mm}$ in $55.7 \%, 0.1-0.9 \mathrm{~mm}$ in $21.3 \%$, while $11.5 \%$ of cases did not undergo any changes or reductions of irregularity. The decrease in the mandibular dental arch depth was significant between the ages of 12 and 21 years in both genders with large effect size $(\eta 2=0.259 ; \mathrm{p}<0.05)$. On average, it amounted to $-0.6 \pm 1.1 \mathrm{~mm}\left(95 \% \mathrm{CI}-0.4-(-0.9)^{\circ}\right)$ (Figure 3).

The amount of change in incisors irregularity did not exhibit linear correlation with the amount of change in sagittal and vertical positions of jaw, inclination of incisors or dental arch depth. Less sagittal growth of maxilla (increase of $\mathrm{SNA} \leq 2^{\circ}$ ) was more frequent in subjects with the increase of crowding of $\geq 1 \mathrm{~mm}$ than in those without the increase of crowding with small effect size (76.7 vs. $44.4 \%$; $\mathrm{p}=0.019$; Cramer $\mathrm{V}=0.314)$. The reduction of convexity of skeletal sagittal interjaw relationship (reduction of $A N B \geq 1^{\circ}$ ) was more frequent in those who exhibited the increase of crowding $(85$ vs. $58.5 \% ; \mathrm{V}=0.264 ; \mathrm{p}=0.046)$. The logistic regression revealed that less sagittal growth of maxilla (increase of SNA $\leq 2^{\circ}$ ) and reduction of skeletal sagittal interjaw relationship (reduction of $A N B \geq 1^{\circ}$ ) were statistically significant categorical predictors of the occurrence of crowding ( $\triangle$ Little Irregularity Index $\geq 1 \mathrm{~mm}$ ) yielding odds ratio of 4.9 and 4.8 (Table 1). The model correctly classified $74 \%$ of all cases; $90 \%$ of cases with the occurrence of crowding, and $40 \%$ without the occurrence of crowding. Gender, sagittal growth of the mandible, vertical skeletal pattern, inclination of maxillary and mandibular incisors, and anterior arch depth did not additionally contribute to the model of prediction of the occurrence of mandibular incisors crowding. bularnoga prognatizma $1,8 \pm 1,6^{\circ}(95 \% \mathrm{CI} 1,4-2,2)$, a kut skeletne klase smanjio se za $-0,5 \pm 1,2^{\circ}(95 \% \mathrm{CI}-0,2-0,8)$. Između 12. i 21. godine dogodilo se značajno smanjenje skeletne vertikalne dimenzije u oba spola $s$ velikom veličinom efekta $(\eta 2=0,527-0,593 ; \mathrm{p}<0,001$; slika 2).

Prosječno smanjenje Bjorkova poligona iznosilo je $-2,9 \pm$ $2,6^{\circ}(95 \% \mathrm{CI}-2,3-(-3,6))$, a intermaksilarnoga kuta $-3,2$ $\pm 2,8^{\circ}(95 \% \mathrm{CI}-2,5-(-3,9))$. Mandibularni sjekutići pokazali su tendenciju retroinklinacije u oba spola (u prosjeku $-1,0 \pm 3,9^{\circ} ; 95 \% \mathrm{CI} 0,0-\left(-1,9^{\circ}\right)$, a maksilarni sjekutići proinklinirali su se kod muškaraca $\left(1,7 \pm 4,9^{\circ} ; 95 \%\right.$ CI $-0,1-$ $\left.3,5^{\circ}\right)$ te imali blagu tendenciju retroinklinacije kod žena $(-0,2$ $\pm 3,7^{\circ} ; 95 \%$ CI $-1,6-1,2^{\circ}$ ); Slika 2). Između 12. i 21. godine značajno je povećan Littleov indeks nepravilnosti $-\mathrm{u}$ prosjeku od 1,8 $\pm 1,7 \mathrm{~mm}(95 \%$ CI 1,3-2,2; $\eta 2=0,520 ; \mathrm{p}<$ $0,001)$, a nalazi su bili slični za oba spola (slika 3.). Povećanje nepravilnosti od $\geq 4 \mathrm{~mm}$ dogodilo se u $11,5 \%$ slučajeva, od 1 do $3,9 \mathrm{~mm} \mathrm{u} 55,7 \%, 0,1$ do $0,9 \mathrm{~mm}$ u $21,3 \%$, a u $11,5 \%$ slučajeva nije bilo promjene ili su se nepravilnosti smanjile. Smanjenje prednje dužine mandibularnoga zubnog luka bilo je značajno u dobi od 12 . do 21 . godine u oba spola s velikom veličinom efekta $(\eta 2=0,259 ; \mathrm{p}<0,05)$. Prosječno je iznosilo $-0,6 \pm 1,1 \mathrm{~mm}\left(95 \% \mathrm{CI}-0,4-(-0,9)^{\circ}\right)$ (slika 3.).

Iznos promjene indeksa nepravilnosti donjih sjekutića nije pokazao linearnu korelaciju s iznosom promjene sagitalnoga i vertikalnoga položaja čeljusti, nagibom sjekutića ili prednjom dužinom zubnoga luka. Manji sagitalni rast maksile (porast $\mathrm{SNA} \leq 2^{\circ}$ ) bio je češći kod ispitanika s povećanjem zbijenosti sjekutića za $\geq 1 \mathrm{~mm}$, negoli kod onih bez povećanja zbijenosti, s malom veličinom efekta ( 76,7 vs. $44,4 \%$; p $=0,019$; Cramerov V = 0,314). Smanjenje konveksiteta sagitalnoga skeletnog međučeljusnog odnosa (smanjenje ANB $\geq$ $1^{\circ}$ ) bilo je češć kod onih sa zbijenošću sjekutića ( 85 prema $58,5 \% ; V=0,264 ; p=0,046)$. Logistička regresija otkrila je da su manji sagitalni rast maksile (porast $\mathrm{SNA} \leq 2^{\circ}$ ) i smanjenje sagitalnoga skeletnoga međučeljusnog odnosa (smanjenje $\mathrm{ANB} \geq 1^{\circ}$ ) bili statistički značajni kategorijski prediktori pojave zbijenosti ( $\Delta$ Littleov indeks nepravilnosti $\geq 1 \mathrm{~mm})$, uz omjer izgleda od 4,9 i 4,8 (tablica 1.). Model je ispravno klasificirao $74 \%$ svih ispitanika; $90 \%$ ispitanika s pojavom zbijenosti i $40 \%$ bez pojave zbijenosti. Spol, sagitalni rast mandibule, skeletni obrazac vertikalnog rasta, nagib maksilarnih i mandibularnih sjekutića te prednja dužina mandibularnoga zubnoga luka nisu dodatno pridonijeli modelu predikcije pojave zbijenosti mandibularnih sjekutića.

Table 1 Logistic regression analysis for prediction of occurence of late madibular incisors crowding

Tablica 1. Logistička regresijska analiza za predikciju pojave tercijarne zbijenosti mandibularnih sjekutića

\begin{tabular}{l|c|c|c|c} 
& B & SE & P & OR (95\% CI) \\
$\triangle \mathrm{SNA} \leq 2^{\circ}$ & 1.6 & 0.6 & 0.014 & $4.9(1.4-17.2)$ \\
\hline$\triangle \mathrm{ANB} \geq 1^{\circ}$ & 1,6 & 0.8 & 0.036 & $4.8(1.1-21.1)$ \\
\hline Constant $\bullet$ Konstanta & $-0,8$ & 0.6 & &
\end{tabular}

Negelkerke Pseudo $\bullet$ Negelkerkeov pseudo $\mathrm{R}^{2}=0.231 ; \mathrm{p}=0.004$.

$\mathrm{B}$ - logistic coefficient $\bullet$ logistički koeficijent, $\mathrm{SE}$ - standard error $\bullet$ standardna pogreška, p - level of significance $\bullet$ razina značajnosti, OR - odds ratio $\bullet$ omjer izgleda, CI - confidence interval $\bullet$ interval pouzdanosti 


\section{Discussion}

This research has shown that the jaws grow during adolescence by moving forwards with the mandible growing more, i.e. longer than maxilla, which is more expressed in males. The occurrence of late mandibular incisor crowding is related to a certain extent to the amount of sagittal jaw growth.

The observed greater increase in the growth of the mandible, especially in males, is confirmed by the previous longitudinal studies $(15,16)$. It is considered that the craniofacial growth in males continues after the age of 18 (17). Some studies have noted a significant jaw growth potential in females during late adolescence (18). Great individual variations were observed within the group of subjects of different genders and of the same age, which raises a question of precision of growth prediction and its application in the prediction of the course and outcome of orthodontic treatment and retention (19). On the other hand, some researchers have not found any significant gender differences in the annual amount of mandibular growth in children and adolescents (20). The reduction of the skeletal class angle found in this study had also been previously reported, and has been related to a slight flattening of the profile (21). The flattening of the profile could be associated with the phenomenon of the human neoteny, which represents slower physical development of features when compared to non-human primates, retaining juvenile facial characteristics in humans longer (22). The reduction of the skeletal vertical dimension occurs regardless of gender. While the vertical growth is the last to be completed, growth in width of both jaws has a tendency of completion before the adolescent growth spurt and shows minimal change within the frame of adolescent changes (17).

The findings of this study have confirmed that the greater i.e., longer growth of the mandible in relation to the maxilla is followed by a dentoalveolar adaptation in the form of retroclination of lower incisors, and the proclination of upper incisors in males, and an decrease in the lower dental arch length. In females, the upper teeth also exhibit retroclination to a certain extent which might indicate a stronger influence of the lips in females. Some studies have also shown that a directed forward growth of the mandible, which could be potentially followed by a forward shift of mandibular teeth, is not present. In fact, a dentoalveolar adjustment occurs with the goal of obtaining intercuspation (23). Previous studies have reported a lingual inclination present in the lower incisors in male subjects during the growth of the mandible (24).

The decrease in the mandibular dental arch depth in both genders between the ages of 12 and 21 years which was confirmed by this research had also been previously reported (25, 26). Some researchers have reported a more considerable decrease in females (27). A possible cause for the decrease in the mandibular dental arch depth is the earlier completion of the growth of the maxilla due to which the lower teeth resist against the upper ones, retroclinate and consequently crowding occurs (28). Some studies have stated a decrease in the length of the maxilla and mandible $(21,29,30)$ as a possible cause of late crowding. The increase in mandibular intercanine width during growth appears to reduce the risk of crowding (31).

\section{Rasprava}

Ovo istraživanje pokazuje da tijekom adolescencije čeljusti rastu prema naprijed, pri čemu mandibula raste više, odnosno dulje od maksile, što je jače izraženo kod muškaraca. Pojava kasne zbijenosti mandibularnih sjekutića u određenoj je mjeri povezana s količinom sagitalnoga rasta čeljusti.

Uočeni veći iznos rasta mandibule, osobito kod muškaraca, potvrđuju dosadašnja longitudinalna istraživanja $(15,16)$. Smatra se da se kraniofacijalni rast kod muškaraca nastavlja i nakon 18. godine (17). U nekim studijama istaknut je značajan potencijal rasta čeljusti kod žena tijekom kasne adolescencije (18). Uočene su velike individualne varijacije unutar skupine ispitanika različitog spola i iste dobi, pa se postavlja pitanje o preciznosti predviđanja rasta i njegovoj primjeni u predviđanju tijeka i ishoda ortodontske terapije i retencije (19). S druge strane, autori nekih istraživanja ne nalaze značajne spolne razlike u godišnjoj količini rasta mandibule kod djece i adolescenata (20). Smanjenje kuta skeletne klase $\mathrm{u}$ ovoj studiji reportirano je i ranije te je povezano s blagim poravnanjem profila donje trećine lica (21). Poravnanje profila moglo bi se povezati s fenomenom humane neotenije koja predstavlja sporiji fizički razvoj u usporedbi s nehumanim primatima, pri čemu se mladenačke značajke lica kod ljudi dulje zadržavaju (22). Smanjenje skeletne vertikalne dimenzije događa se bez obzira na spol. Iako je vertikalni rast posljednji koji se završava, transverzalni rast obiju čeljusti ima tendenciju završiti prije pubertetskog vrhunca rasta te pokazuje minimalne promjene $\mathrm{u}$ sklopu adolescentnih promjena (17).

Nalazi iz ove studije potvrđuju da veći, odnosno duži rast mandibule u odnosu na maksilu prati dentoalveolarna adaptacija u obliku retroinklinacije madibularnih sjekutića, proinklinacije maksilarnih sjekutića kod muškaraca te smanjenja prednje dužine mandibularnoga zubnoga luka. Kod žena gornji zubi pokazuju u određenoj mjeri retroinklinaciju, što bi moglo upućivati na jači utjecaj usana. $U$ istraživanju je također istaknuto da usmjereni rast mandibule prema naprijed, koji bi mogao biti praćen prednjim pomakom mandibularnih zuba, nije prisutan. Zapravo se događa dentoalveolarna prilagodba kako bi se postigla interkuspidacija (23). Lingvalni nagib mandibularnih sjekutića tijekom rasta mandibule uočen je i prije kod muškaraca (24).

Smanjenje prednje dužine mandibularnoga zubnoga luka u oba spola u dobi od 12. do 21. godine, potvrdeno u ovom istraživanju, reportirano je i ranije $(25,26)$. Neki reportiraju značajnije smanjenje kod žena (27). Mogući uzrok smanjenja dužine mandibularnoga zubnoga luka je raniji završetak rasta maksile zbog čega se donji zubi odupiru o gornje, retroinkliniraju, čime se posljedično pojavljuje zbijenost (28). Kao mogući uzrok tercijarne zbijenosti, u nekim se studijama navodi smanjenje dužine gornje i donje čeljusti $(21,29,30)$. Čini se da povećanje mandibularne interkanine širine tijekom rasta smanjuje rizik od pojave zbijenosti (31).

Uočen je generacijski trend smanjenja visine lica (32). No horizontalni rast čeljusti ne upućuje na povećanje stupnja zbijenosti (33), a u nekim istraživanjima autori ne uspostavljaju korelaciju između zbijenosti i skeletne vertikalne dimenzije $(34,35)$. Suprotno tomu, u nekim istraživanja izvješta- 
A generational trend of facial height decrease has been reported (32). However, horizontal growth of the jaw does not indicate an increase in the degree of crowding (33), and some studies have not found a correlation between crowding and vertical skeletal dimensions $(34,35)$. Conversely, some studies have reported a bigger degree of late crowding in subjects with the hyperdivergent jaw growth and increased lower third of the face (21). Others cite increased upper portions of the face, an increase in the mandibular angle and a decrease in the length of the mandible, i.e., the SNB angle $(36,37)$. Increased values of Little's Index mark a greater degree of crowding, although certain studies question the value of Little's Index and have found it limited in accuracy and precision, which may also be a limitation of the present study (38). For a long time the eruption of third molars was considered the leading cause of crowding, but research has not found a causal connection because the eruption of third molars simply coincides in time with the occurrence of late mandibular incisor crowding $(39,40)$. The etiology of late mandibular incisor crowding is multifactorial. Leading theories suggest that the problem is caused either by mesial movement of posterior teeth or by lingual movement of anterior teeth. Other theories attribute late crowding to the growth of jaws, occlusion, dental arch dimensions, tooth size, masticatory forces. In addition, a periodontal disease with the loss of alveolar bone can also contribute to it (41).

\section{Conclusion}

During adolescence, between ages 12 to 21 , a longer, i.e., greater growth of mandible is observed compared to maxilla. This is especially prominent in males. A greater mandibular growth is accompanied by mandibular incisor retroclination and a decrease in the mandibular dental arch depth and the occurrence of mandibular incisor crowding. The differential sagittal growth of the maxilla and mandible is related to the occurrence of late crowding. It has been established that mandible grows more in amount and for longer duration than maxilla.

\section{Acknowledgements}

This study was created under the projects UNIRI BIOMED 18-22 and UNIRI BIOMED 18-71 and financed by the University of Rijeka. We thank the employees of the Department of Orthodontics at the Institute of Clinical Dentistry of the University of Oslo, Norway for the access to the Nittedal Growth Study materials.

\section{Conflict of interest}

The authors declare no conflict of interest.

Author's contribution: S.S., A.P., V.V.R. - conceptualization; S.S., A.P., D.M. - Methodology; S.S, A.P. - Statistical Analysis; D.M., M.Z., A.M. Investigation; D.M., A.P., M.Z. - Formal Analysis; D.M., A.P., M.Z. - Resources; D.M., A.P., V.V.R., M.Z., A.M. - Data curation; D.M., A.P. - Writing - original draft preparation; M.Z., A.M., S.S. - Writing - review \& editing; V.V.R., S.S. - Supervision; V.V.R., S.S. - Project Administration; M.Z., S.S. - Funding Acquisition. va se o većem stupnju tercijarne zbijenosti kod ispitanika $s$ hiperdivergentnim rastom čeljusti i povećanom donjom trećinom lica (21). Drugi istraživači navode povećanje gornjih dijelova lica, povećanje mandibularnoga kuta i smanjenje dužine mandibule, tj. SNB kuta $(36,37)$. Povećane vrijednosti Littleova indeksa označuju veći stupanj zbijenosti, iako istraživači u određenim studijama dovode u pitanje vrijednost Littleova indeksa smatrajući ga ograničenim u točnosti i preciznosti, što može biti ograničenje i u ovoj studiji (38). Nicanje trećih kutnjaka dugo se smatralo jednim od glavnih uzroka zbijenosti sjekutića, no u istraživanjima nije pronađena uzročna veza zato što se nicanje trećih kutnjaka jednostavno vremenski podudara $s$ pojavom tercijarne zbijenosti mandibularnih sjekutića $(39,40)$. Etiologija tercijarne zbijenosti mandibularnih sjekutića vjerojatno ima multifaktorijalni karakter koji uključuje rast čeljusti, okluziju, dimenzije zubnih lukova, veličinu zuba i žvačne sile, a čemu može pridonijeti i parodontna bolest s gubitkom alveolarne kosti (41).

\section{Zaključak}

Tijekom adolescencije, od dobi od 12. do 21. godine, uočen je duži, tj. veći rast mandibule u odnosu prema maksili, što je posebno istaknuto kod muškaraca. Veći rast donje čeljusti prati retroinklinacija mandibularnih sjekutića i smanjenje dužine mandibularnoga zubnoga luka te zbijenost mandibularnih sjekutića. Diferencijalni sagitalni rast maksile i mandibule povezan je s pojavom tercijarne zbijenosti, uglavnom zbog manje količine sagitalnoga rasta maksile u odnosu prema mandibuli.

\section{Zahvala}

Studija je nastala u sklopu projekata UNIRI BIOMED 18-22 i UNIRI BIOMED 18-71 koje financira Sveučilište u Rijeci. Zahvaljujemo zaposlenicima Zavoda za ortodonciju Instituta za kliničku dentalnu medicinu Sveučilišta u Oslu, Norveška na pristupu materijalima Nittedalske studije rasta.

\section{Sukob interesa}

Autori nisu bili u sukobu interesa.

Doprinosi autora: S. S., A. P., V.V.R. - koncept istraživanja; S. S., A. P., D. M. - metodologija; S. S, A. P. - statistička analiza; D. M., M. Z., A. M. - provedba istraživanja; D. M., A. P., M. Z. - analiza podataka; D. M., A. P., M. Z. - resursi podataka; D. M., A. P., V. V. R., M. Z., A. M. menadžment podataka; D. M., A. P. - pisanje koncepta izvornog rukopisa; M. Z.,A. M.,S. S. - pisanje - sugestije i korekcije; V. V. R., S. S. supervizija; V. V. R., S. S. - vođenje projekta istraživanja; M. Z., S. S. - stjecanje financiranja 
Sažetak

Cilj: Analizirati kraniofacijalni rast tijekom adolescencije u dobi od 12. do 21. godine i njegovu povezanost s kasnom zbijenošću mandibularnih sjekutića. Metode: U studiji je sudjelovao 61 ortodontski netretirani ispitanik ( $49 \%$ muškaraca). Za procjenu rasta čeljusti i nagiba sjekutića korišteni je laterolateralni kefalogram. Izmjereni su Littleov indeks nepravilnosti i prednja dužina donjega zubnog luka. Rezultati: Uočeno je smanjenje kuta skeletne klase (ANB) kod oba spola, iako značajno samo kod muškaraca $(\eta 2=0,188 ; p=0,015)$. Mandibula je rasla više od maksile i to više kod muškaraca negoli kod žena. No, skeletna vertikalna dimenzija pokazala je značajno smanjenje u oba spola $(\eta 2=0,527$ $-0,593, p<0,001)$. Mandibularni sjekutići imali su tendenciju retroinklinacije u oba spola, a maksilarni su bili skloni proklinaciji kod muškaraca te blažoj retroinklinaciji kod žena. Primijećeno je smanjenje prednje dužine donjega zubnog luka u oba spola $(\eta 2=0,259 ; p<0,05)$. Povećanje nepravilnosti sjekutića u prosjeku je iznosilo $1,8 \pm 1,7 \mathrm{~mm}(95 \% \mathrm{Cl} 1,3-2,2 ; \eta 2=0,520 ; p<0,001)$, a uočeno je $u$ oba spola. Logistička regresija otkrila je da su manji sagitalni rast maksile (povećanje kuta SNA $\leq 2^{\circ}$ ) i smanjenje konveksiteta sagitalnoga međučeljusnog odnosa (smanjenje ANB $\geq 1^{\circ}$ ) bili značajni prediktori nastanka zbijenosti ( $\Delta$ Littleov indeks nepravilnosti $\geq 1 \mathrm{~mm}$ ) dajući omjere izgleda od 4,9 i 4,8. Zaključci: Diferencijalni rast maksile i mandibule povezan je s pojavom kasne zbijenosti mandibularnih sjekutića uglavnom zbog manje količine sagitalnoga rasta maksile u odnosu na mandibulu.
Zaprimljen: 11. studenoga 2020.

Prihvaćen: 19. siječnja 2021.

Adresa za dopisivanje

Martina Žigante

Kresimirova 40

51000 Rijeka, Hrvatska

faks: +38551345650,

martina.zigante@uniri.hr

MeSH pojmovi: čeljust; rast; malokluzija; sjekutić; adolescent

Autorske ključne riječi: rastući ispitanici, malokluzija, adolescencija, kefalometrija, zbijenost

\section{References}

1. Opperman L. Cranial sutures as intramembranous bone growth sites. Dev Dyn. 2000 Dec;219(4):472-85.

2. Premkumar S. Textbook of craniofacial growth. New Delhi: Elsevier; 2015.

3. Carlson D. Theories of craniofacial growth in the postgenomic era. Semin Orthod. 2005;11:172-83.

4. 4. Enlow DH, Hans MG. Essential of facial growth. Philadelphia: WB Saunders; 1996.

5. Pasciuti E, Franchi L, Baccetti T, Milani S, Farronato G. J Orofac Orthop. 2013 Sep;74(5):397-408.

6. Baer MJ. Patterns of growth of the skull as revealed by vital stain ing. Hum Biol. 1954;26:80-126.

7. Castaldo G, Cerritelli F. Craniofacial growth: evolving paradigms. Cranio. 2015 Jan;33(1):23-31.

8. Bjork A. The use of metallic implants in the study of facial growth in children: Method and application. Am J Phys Anthropol. 1968;29:243-54.

9. 9. Legović M, Cehić A. Longitudinal analysis of the development of eugnathia and dysgnathia from the primary dentition to the permanent dentition. Acta Stomatol Croat. 1986;20:3-9.

10. Richardson ME. Late lower arch crowding in relation to skeletal and dental morphology and growth changes. $\mathrm{Br} J$ Orthod. 1996;23:249-54.

11. Ihlow D, Kubein-Meesenburg D, Fanghänel J, Lohrmann B, Elsner $\mathrm{V}$, Nägerl H. Biomechanics of the dental arch and incisal crowding. J Orofac Orthop. 2004;65:5-12.

12. Sidlauskas A, Trakiniene G. Effect of the lower third molars on the lower dental arch crowding. Stomatologija. 2006;8:80-4.

13. Muretic Z, Lapter Varga M. New parameters for roentgencephalometric analysis, Zagreb 82 MOD“. Acta Stomatol Croat. 2004:38:169-72.

14. Little RM. The irregularity index: a quantitative score of mandibular anterior alignment. Am I Orthod. 1975;68:554-63.

15. Helder B, Buschang JP. Mandibular growth comparisons of class I and class II division 1 skeletofacial patterns. Angle Orthod. 2014;84:755-61.

16. Ferrario V, Sforza C, Poggio C, Schmitz J. Craniofacial growth: A three-dimensional soft-tissue study from 6 years to adulthood. J Craniofac Genet Dev Bio. 1998;18:138-49.

17. Snodell S, Nanda R, Currier G. A longitudinal cephalometric study of transverse and vertical craniofacial growth. Am J Orthod Dentofac Orthop. 1993;104:471-83.

18. Foley T, Mamandras A. Facial growth in females 14 to 20 years of age. Am J Orthod Dentofac Orthop. 1992;101:248-54.

19. Nanda R, Ghosh. J. Longitudinal growth changes in the sagittal relationship of maxilla and mandible. Am J Orthod. 1995;107:79-90.

20. Gomes A, Martinelli De Lima E. Mandibular growth during adolescence. Angle Orthod. 2006 Sep;76(5):786-90.

21. Rasul G, Kamran M, Khan A, Farhat W. The role of sagittal param eters in the development of lower incisor crowding amongst patients. J Khyber Coll Dent. 2012;3:37-40.

22. Šimić G, Vukić V, Kopić J, Krsnik Ž, Hof PR. Molecules, mechanisms, and disorders of self-domestication: keys for understanding emotional and social communication from an evolutionary perspective. Biomolecules. 2020;11:E2.
23. You Z, Fishman L, Rosenblum R, Subtelny J. Dentoalveolar chang es related to mandibular forward growth in untreated class II persons. Am J Orthod Dentofacial Orthop. 2001 Dec;120(6):598-607; quiz 676.

24. Love R, Murray J, Mamandras A. Facial growth in males 16 to 20 years of age. Am J Orthod Dentofac Orthop. 1990;97:200-6.

25. Harris EF. A longitudinal study of arch size and form in untreated adults. Am J Orthod Dentofac Orthop. 1997;111:419-27.

26. Newcomb MR. The anatomic and physiologic factors influencing denture arch form and a discussion of the part played by each. Angle Orthod. 1936;6:39-46.

27. Paulino V, Paredes V, Cibrian R, Gandia J. Dental arch chang es from adolescence to adulthood in a Spanish population: A cross-sectional study. Med Oral Patol Oral Cir Bucal. 2011 Jul $1 ; 16(4): e 607-13$

28. Fastlicht J. Crowding of mandibular incisors. Am J Orthod. 1970;58:156-63.

29. Leighton B, Hunter S. Relationship between lower arch spacing/ crowding and facial height and depth. Am J Orthod. 1982;82:41825.

30. Khoja A, Fida M, Shaikh A. Association of maxillary and mandibular base lengths with dental crowding in different skeletal malocclusions. J Ayub Med Coll Abbottabad. Oct-Dec 2014;26(4):42833.

31. Zigante M, Pavlic A, Vandevska Radunovic V, Mathewson A, Kotarac Knezevic A, Spalj S. Changes of mandibular dental arch shape during adolescence and its influence on late mandibular incisor crowding. Homo. 2019;70:185-192.

32. Gazi-Coklica V, Muretic Z. Secular trend as a factor of craniofacial morphological changes. Acta Stomatol Croat. 1991;25:135-42.

33. Richardson M. Late lower arch crowding: The role of differential horizontal growth. Br J Orthod. 1994;21:379-85.

34. Miethke RR. No correlation between primary mandibular anterior crowding and vertical craniofacial configuration or lower incisor inclination. J Orofac Orthop. 2000;61:297-04.

35. Rasul G, Khan A, Qiam F. The role of vertical parameters in the development of lower incisor crowding amongst patients. J Khyber Coll Dent. 2012;3:37-40.

36. Sakuda M, Kuroda Y, Wada K, Matsumoto M. Changes in crowding of teeth during adolescence and their relation to the growth of the facial skeleton. Trans Eur Orthod Sot 1976;93-104.

37. Berg R. Crowding of the dental arches: a longitudinal study of the age period between 6 and 12 years. Eur J Orthod. 1986;8:43-9.

38. Macauley D, Garvey T, Dowling A, Fleming G. Using Little's irreg ularity index in orthodontics: Outdated and inaccurate? J Dent. 2012 Dec;40(12):1127-33.

39. Ades A, Joondeph D, Little R, Chapko M. A long-term study of the relationship of third molars to changes in the mandibular dental arch. Am J Orthod Dentofac Orthop. 1990;97:323-35.

40. Hasegawa Y, Terada K, Kageyama I, Tsuchimochi T, Nakahara $\mathrm{S}$. Influence of third molar space on angulation and dental arch crowding. Odontology. 2013 Jan;101(1):22-8.

41. Richardson M. The etiology of late lower arch crowding alternative to mesially directed forces: a review. Am J Orthod Dentofacial Orthop. 1994;105:592-7. 